\title{
Transformation of Cultural Concepts Within the Conceptual Sphere of a Literary Text (on the Material of the Short Story by R. Bradbury "The Smiling People")
}

\author{
Inna V. Kononova* \\ St. Petersburg State University of Economics \\ 21 Sadovaya, St. Petersburg, 191011, Russia
}

Received 18.09.2015, received in revised form 06.10.2015, accepted 09.11.2015

\begin{abstract}
The article is written in the line with cognitive poetics, one of the actively developing fields of linguistic poetics. Cognitive poetics regards different stages of functioning of works of art, considered from the point of view of mental categories: the author (the individual conceptual sphere) - the artistic reality (the conceptual structure of a literary text) - the reader (the cognitive mechanisms of perception). The cognitive approach to the analysis of a literary text gives the possibility to describe the individual conceptual sphere of an author, which is understood as the mental base of a writer's style, and to describe the transformation of the structure of cultural concepts under the influence of an author's mentality.
\end{abstract}

Keywords: cognitive poetics, concept, conceptual sphere of a literary text, the individual conceptual sphere of an author, concept structure.

DOI: $10.17516 / 1997-1370-2015-8-12-2868-2874$.

Research area: philology.

\section{Introduction}

Extrapolation of the cognitive paradigm on literary texts allows to identify individual concepts that form the conceptual sphere of a writer and to describe the means of their linguistic representation. The individual conceptual sphere of an author is understood by most scholars as the mental base of the individual style of an author (Butakova, 2002; Rudneva 2007, etc.).

The term «cognitive poetics» refers to a set of «semantic, conceptual and semiotic techniques aimed at clarifying the cognitive motivation of any aesthetically significant components and the entire text as a whole» (Butakova 2002: 85). The new approach to the analysis of a literary text is focused on describing the transformations of the structure of cultural concepts within the individual conceptual sphere created by an author.

In our further analysis we will proceed from the following propositions:

1. An author's individual concept is a dynamic component of culture. Its formation may present either transformation of a cultural concept with the same name or creation of a new concept that

(C) Siberian Federal University. All rights reserved

* Corresponding author E-mail address: inkon_71@mail.ru 
does not exist in the culture (when we deal with literary texts belonging to such genres as science fiction, fantasy, fairy tale, the genre of absurd, etc.) and is generated to reflect some aspect of the so-called alternative world.

2. Individual author's concepts form the conceptual sphere which is understood as the mental base of a writer's style.

From this perspective, we'll make an attempt of analysis of the structure and language representation of the author's individual concepts objectivized in Raymond Douglas Bradbury's short story «The smiling people» (published in 1947).

\section{Theoretical framework and methods}

By present time cultural studies in linguistics have developed a number of approaches to identifying the structure of a cultural concept. Most currently known approaches, underlying a number of recent studies, belong to Yu. S. Stepanov (2004), V. I. Karasik (1996, 2005), I. A. Sternin (Popova, Sternin, 2001), S.G. Vorkachev (2004) and G. G. Slyshkin (2004).

We have proposed an approach to modeling the structure of a cultural concept developing the above-mentioned conceptions. In accordance with the proposed approach, the structure of a cultural concept includes the perceptional (image), associative, notional, axiological (value) and etymological components (Kononova, 2010: 91-104).

The image (perceptional) component of a concept may include a visually-perceptible representation or a combination of conceptual metaphors deduced by a native speaker from the collocations of the word(s), representing the concept in the language. The associative component of a cultural concept is formed by the dominant associative relations of the language representatives of a concept. The notional component of a concept has the intersection zones with the associative one as it can be drawn from the dominant associative links of a concept. However the generic features of a concept constitute the basic part of the notional component. The value component of a concept, according to G.G. Slyshkin, can be decomposed into two measurable aspects: relevance and evaluation. The evaluative aspect is reflected by the presence of the evaluation component in the meaning of a language unit, naming a concept, or in combinations of this unit with emotive lexis. The aspect of relevance is implemented in the number of language units, which are the means of appealing to this concept in various discourse conditions. The presence of the relevance aspect is verified by quantitative counting (Slyshkin, 2004: 23). The etymological component of a concept ("etymological layer" (Stepanov, 2004) is determined by the internal form of the word, which is the key representative of a concept. The etymological component of a concept serves as a means of additional motivation of its value component.

The main attention in the study of cultural concepts within the conceptual sphere of a literary text should be given to the image, value and associative components, as the latter are subjected to verification by language facts and influenced by the discursive conditions to a great degree.

\section{Discussion}

The collection of short stories "Dark Carnival" was the writer's first published collection (1947). The collection introduces us to a very «black» Bradbury as the key concept if it is death. "Dark Carnival" very soon got recognition of the public and was unanimously considered a very «weird» book. It's not very easy to exactly state the genre of the collection. Being written in the epoch of post-modernism in literature it demonstrates the features of quite a number of 
styles and genres: fantasy, socio-philosophical fiction, romanticism, naturalism, etc. According to R. Bradbury himself it was written under the influence of Edgar Allan Poe's creative work. Poe's best known fiction works are Gothic, a genre he followed to appease the public taste. His most recurring themes deal with questions of death, including its physical signs, the effects of decomposition, concerns of premature burial, the reanimation of the dead, and mourning. Many of his works are generally considered part of the dark romanticism genre.

The plot of the story "The Smiling People" unfolds in Mr. Greppin's house. The main character - Mr. Greppin - comes home and feels absolutely satisfied with the profoundness of silence around him. He comes to the dining room and talks to his relatives sitting quietly at dinner table. Only at the end of the story, with the arrival of the police, the reader fully understands that Mr. Greppin had killed his aunt, uncle and two nephews two week before and attached their dead bodies to the chairs. The reader understands that the main character (being mentally ill of course) killed his relatives because they hadn't let him live his own life oppressing and humiliating him for years. It's implied between the lines that when a child Mr. Greppin had lost his parents and had been brought up by his aunt who, being callous and narrow-minded, totally disfigured his personality.

The concept DEATH, obviously central in the cognitive space of the literary text in focus, is not realized directly but for two lexemes which do not refer to the incident of the murder immediately (encoffined silence; its (clock's) long cedar, glassfronted coffin). Instead the author introduces into the story the image of death, describing old Aunt Rose as its personification:

"Her breasts had not been exhumed for years; either for love or child-sucking. They were mummies wrapped in cerements and put away for all time. Beneath the table her stick legs in high button shoes went up into a sexless pipe of dress. You felt that the legs terminated at the skirt line and from there on she was a department store dummy, all wax and nothingness. You felt that her husband, years ago, must have handled her in just such a way as one handled window mannequins, and she responded with the same chill waxen movements, with as much enthusiasm and response as a mannequin." The words mummies, store dummy, window mannequins suggest the idea of spiritual death of a person who being in charge of an orphan crippled the young soul. The motive of a hypocritical, stupid and egoistic woman (the embodiment of spiritual death) breaking the life and soul of a young person is one of the recurrent motives in R. Bradbury's creative work (e.g. Some Live like Lazarus).

The conceptDEATH is represented indirectly by the lexemes realizing the concepts that become within the conceptual sphere of the story the signs of its associative component: SILENCE, JOY and FEAR. This absence of direct representation of the central concept obviously helps to create suspense in the story: from the very first passages the reader feels growing atmosphere of danger.

The method of quantitative calculation allowed to find out that the concept SILENCE is the most frequently represented in the text.

\begin{tabular}{|l|c|l|c|}
\hline & $\begin{array}{c}\text { the } \\
\text { number } \\
\text { of occur- } \\
\text { rences }\end{array}$ & & $\begin{array}{c}\text { the } \\
\text { number } \\
\text { of occur- } \\
\text { rences }\end{array}$ \\
\hline silence & 26 & mute & 1 \\
\hline silent & 4 & no sound & 2 \\
\hline silently & 1 & soundless & 1 \\
\hline quiet & 4 & soundlessness & 1 \\
\hline quietly & 2 & no noise & 2 \\
\hline
\end{tabular}

Thus, the key-words representing the concept directly constitute $1,2 \%$ (43 lexemes) of the total number of words (3649), but it is also realized indirectly in a great number of contexts by the 
whole sentence or passage, by stylistic devices or figures of speech. E.g.:

"The double carpet in the hall, which he himself had so recently laid, gave off no sound from his movements..."

"The only sound was the merest allowable pad of his shoes on the deep carpet..."

"The double carpet was thick and soundless underfoot, reassuring"

"The grandfather clock had been stilled..."

"There was not a stir of knife or fork from the dining-table..."

"Each sound was a fear. So each sound had to be muffled, gotten to and eliminated.

"...there was not a rattle of eave or tremor of loose sash."

"...there was not a stir of knife or fork from the dining-table."

"There was no whispering. There could be none in his house"

The word whispering representing the concept indirectly (whispering implies the intention to produce little noise) is used in the text 7 times, the word whisper -1 time, whispers -2 times.

Thus, the concept SILENCE is organizing the cognitive space of the story and it's really possible to suppose that the story is about silence, its types and characteristic features, about the main character's unusual ability to enjoy silence to quite an extraordinary extent. But in the first case of occurrence of language units objectivizing the concept it becomes apparent that within the conceptual sphere of the short story it is associated with the concept DEATH:

"As Mr. Greppin came through the front door the oiled silence of the door opening and swinging close behind him... Weighing the silence with the remarkable instruments of pitch and balance in his small ears, he nodded with satisfaction that the silence was so unified and finished. Even the grandfather clock had been stilled, its brass pendulum hung frozen and gleaming in its long cedar, glass-fronted coffin".

The word silence is used in the narrow context with the word coffin that immediately eliminates signs "peace" and "calmness" (inherent in the concept SILENCE at the level of the national conceptual sphere) from its structure in this discursive realization. This fact is confirmed by the cases of attributive-predicative compatibility of the word silence. The adjectival and verbal metaphors (oiled silence, weighing the silence) and word combinations demonstrating the violation of lexical combinability of the abstract noun silence (unified silence, finished silence) prove the fact that we deal with some kind of abnormal silence in the house though Mr. Greppin enjoys it very much.

The idea of the "quality of silence", the longing of the main character to acquire some kind of the "best, complete, finished" silence hints at some desired spiritual state, some emotion that the main character is desperately trying to achieve. Is possible to conclude that this desired spiritual state if freedom ("encoffined" silence, silence "ready to ready to burst free"). E.g.:

«There are silences and silences... There were summer night silences, which weren't silences at all, but layer on layer of insect chorals and the sound of electric lamps swaying in lonely small orbits on lonely country roads, casting out feeble rings of illumination upon which the night fed-summer night silence which, to be a silence, demanded an indolence and a neglect and an indifference upon the part of the listener. Not a silence at all! And there was a winter silence, but it was an encoffined silence, ready to burst free at the first nod of spring...»...

It's evident that within the conceptual sphere of the text the sign FREEDOM is generated in the associative component of the concept SILENCE. But in this discursive realization being in the same associative chain with the concept DEATH 
the concept FREEDOM acquires negative evaluation. No matter how strongly a murderer might dream of "bursting free" he never possibly can.

Another concept that is rather relevant in the conceptual sphere in question is JOY. The concept is realized by numerous lexical units: to make someone smile (10), smiled (3), smile n. (3), enjoy (3), laugh v. (3), pleasure (2). The words representing the concept are used in the conditions of narrow context with the lexemes objectivizing the concepts SILENCE. E.g.:

"First he would make them silent, then he would make them smile, then, later, he would move them out like luggage".

"Two weeks ago he had made them silent and smile".

The word combination "to make someone silent and smile" is used in the story in the meaning "to kill". Literally the main character killed his relatives cutting their throats from ear to ear, figuratively he made them "silent" = "not shouting at him, not criticizing and abusing him" and "smiling" = "being happy for him, joyful, supporting and reassuring him". It's important to note that the word reassuring is used in the story twice.

The word combination "to make someone smile" is used in the story ten times, in all the context it simultaneously represents two concepts: DEATH and JOY. E.g.:

"I said I loved her and wanted to marry her to get around somehow to make you smile. Yes, I said it because I planned to make you smile, that was the only reason. I'm never going to have a woman, I always knew for years I never would have... Will you please pass the potatoes, Aunt Rose?"

"Greppin became introspective. The day he had made them smile. Two weeks ago it was. He had come home, walked in, looked at them and said, 'I'm to be married!'”
The concept DEATH has so strong negative evaluation in the culture that the fact of placing it in the associative chain SILENCE - JOY DEATH doesn't change its evaluation into positive but induces negative evaluation in the structure of the concepts SILENCE and JOY, normally neutral or positive. This shift in the evaluation of the concepts creates a macabre atmosphere of the story, causes in the reader feelings of repulse and danger.

The concept FEAR is the forth concept relevant in the cognitive space of the story. In the analyzed discourse conditions it becomes the part of the associative components of the concepts SILENCE, DEATH and JOY. It is objectivized by 8 lexical units (fear (v.) -2 , fear (n.) -3 , terrify -1 , to go mad -1 , horrid -1 ) and is numerously realized in the text indirectly. E.g.:

"He felt like a mouse running in a great clear space..."

"Sweat began to seep down his body..."

“'Ah!' he cried, leaping up. Then, staring, he sank down, mouth convulsing."

"He hoped the neighbours hadn't heard him shrieking like a fool."

The concept FEAR is intensely associated in the conceptual sphere of the English language with the concept DEATH, but does not have so strong associative links with the concept SILENCE and is not normally associated with the concept JOY.

\section{Conclusion}

So we can conclude that within the conceptual sphere represented in the story the cultural concepts undergo considerable changes in their structure being placed into unusual discourse conditions. The shifts can be observed in its perceptional, value and associative components of the concepts DEATH, SILENCE and JOY. The image component of the concept DEATH is created by the description of Aunt Rose. The 
associative component contains as dominant signs the concepts SILENCE, FEAR and JOY. The latter is not inherent in the structure of the cultural concept DEATH at the level of the national conceptual sphere

The evaluation aspect of the concept DEATH also undergoes some change under the influence of the concepts SILENCE and JOY. It does not become positive but acquires sings of contradictory vectors that might neutralize each other. That "neutralization" of the value perception of death obviously strikes the reader as abnormal and makes them feel horror, disgust and pity for the main character. The same can be stated about the associative components of SILENCE and JOY which, in the analyzed conceptual sphere, contain the concepts DEATH and FEAR. This fact obligatorily influences the evaluation of the concepts SILENCE and JOY, shifting it to the negative.

The most typical transformation of the structure of a cultural concept in the author's individual concept sphere is change of the vector of evaluation to the opposite one. The process is accompanied by the radical transformation of the image and associative components, which inevitably leads to a change in the symbolic potential of a concept.

\section{References}

Bradbury,R.TheSmilingPeople, Availableat:http://mirandamolina.tumblr.com/post/20184278361/ the-smiling-people-ray-bradbury (accessed 25 August 2015).

Butakova, L.O. Postulates of cognitive poetics [Postulaty kognitivnoi poetiki]. Cognitive modeling. Text processing and cognitive technologies Vol. 7). Kazan State University Press, 2002, p. 84-94.

Karasik, V.I. Cultural concepts: the problem of values [Kulturnye koncepti: promlema tsennostey]. Linguistic personality: cultural concepts, Collection of proceedings. Volgograd, Peremena, 1996, p. $3-16$.

Karasik, V.I., Prohvacheva, O.G., Zubkova, Ya.V., Graborova, E.V. The Other Mentality [Inaya mentalnost']. Moscow, Gnozis, 2005. 352 p.

Kononova, I.V. The structure and language representation of the British ethical concept sphere [Struktura i yazykovaya reprezentatsiya britanskoi natsionalnoi moralno-eticheskoi kontseptosphery] Diss. ... d-ra filol. nauk: 10.02.04. - St. Petersburg State University of Economics Press, 2010. 361p.

Popova, Z.D., Sternin, I.A. The interpretation field of a national concept and the methods of its description [Interpretatsionnoye pole natsionalnogo kontsepta i metody ego izugheniya]. Communication culture and its formation. Vol. 8. Voronezh State University Press, 2001, p. 34-56.

Rudneva, O.V. (2007). The conceptualization of the natural space in the short stories by I. Bunin [Kontseptualizatsiya prirodnogo prostranstva in the short stories by I. Bunin]. Vestnik of Moscow State Regional University. "Russian Philology" section, 2, 87-90.

Slyshkin, G.G. Cultural concepts and Metaconcepts (Lingvokulturnye kontsepty i metakontsepty). Volgograd, Peremena, 2004. 340 p.

Stepanov, Yu.S. The Constants: The Thesaurus of Russian Culture [Konstanty: Slovar russkoi kultury]. Moscow, Aкаdem. Proekt, 2004. 991p.

Vorkachev, S.G. Happiness as a cultural concept [Schastiye kak ligvokulturnyi concept]. Moscow, Gnozis, 2004. 236 p. 


\section{Трансформация лингвокультурных концептов \\ в рамках концептосферы художественного текста \\ (на материале рассказа Р. Брэдбери \\ «Улыбающиеся люди»)}

И.В. Кононова

Санкт-Петербургский государственный

экономический университет

Россия, 191011, Санкт-Петербург, ул. Садовая, 21

Статья написана в русле когнитивной поэтики - активно развивающегося в настоящее время направления лингвопоэтических исследований. В сфере компетенции когнитивной поэтики находятся различные этапь функционирования художественного произведения, рассмотренные под углом зрения ментальных категорий: автор (индивидуальная концептосфера) художественная реальность (концептуальная структура текста) - читатель (когнитивные механизмы восприятия). Когнитивный подход к анализу художественного текста позволяет исследовать индивидуально-авторскую концептосферу, которая понимается как ментальная база идиостиля писателя, а также описать трансформации содержания лингвокультурньх концегтов в авторском сознании.

Ключевые слова: когнитивная поэтика, концепт, концептосфера художественного текста, индивидуально-авторская концептосфера, структура концепта.

Научная специальность: 10.00.00 - филологические науки. 